\title{
Reclassification of Leptospira parva Hovind- Hougen et al. 1982 as Turneriella parva gen. nov., comb. nov.
}

\author{
P. N. Levett, ${ }^{1}$ † R. E. Morey, ${ }^{1}$ R. Galloway, ${ }^{1}$ A. G. Steigerwalt ${ }^{1}$ and W. A. Ellis ${ }^{2}$ \\ ${ }^{1}$ Meningitis and Special Pathogens Branch, Division of Bacterial and Mycotic Diseases, \\ National Center for Infectious Diseases, Centers for Disease Control and Prevention, Atlanta, \\ GA, USA \\ ${ }^{2}$ Veterinary Sciences Division, Stoney Road, Stormont, Belfast BT4 3SD, UK
}

\author{
Correspondence \\ P. N. Levett \\ plevett@health.gov.sk.ca
}

Leptospires were traditionally classified as belonging to two species, Leptospira interrogans and Leptospira biflexa, comprising pathogenic and non-pathogenic strains, respectively (Johnson \& Faine, 1984). A more complex classification, based upon DNA-DNA relatedness, recognizes 13 species with validly published names and four as yet unnamed genomospecies (Brenner et al., 1999; Perolat et al., 1998; Ramadass et al., 1992; Yasuda et al., 1987).

Leptospira parva strain $\mathrm{H}^{\mathrm{T}}$ was isolated from contaminated bovine albumin liquid culture medium, and was recognized as being distinct from strains belonging to both existing species of the genus Leptospira (Hovind-Hougen et al., 1981). Moreover, the $\mathrm{G}+\mathrm{C}$ content differed markedly from that of strains of other Leptospira species (Hovind-Hougen et al., 1981). That Leptospira parva was not closely related to other species within the genus was further confirmed by DNA-DNA relatedness studies (Yasuda et al., 1987) and $16 \mathrm{~S}$ rRNA gene sequencing (Hookey et al., 1993) (Fig. 1).

A second strain, S-308-81 (=ATCC BAA-1112), was isolated from the uterus of a sow in Northern Ireland. The $16 \mathrm{~S}$ rRNA gene sequence of this strain was found to be identical to that of strain $\mathrm{H}^{\mathrm{T}}$. DNA was extracted from strains $\mathrm{H}^{\mathrm{T}}$ and S-308-81 and purified, as described previously (Brenner et al., 1982). DNA from strain $\mathrm{H}^{\mathrm{T}}$ was labelled with $\left[{ }^{32} \mathrm{P}\right] \mathrm{dCTP}$ (Brenner et al., 1999), and the DNA-DNA relatedness and percentage divergence between the two strains

Published online ahead of print on 17 February 2005 as DOI 10.1099/ ijs.0.63088-0.

†Present address: Provincial Laboratory, Saskatchewan Health, 3211 Albert Street, Regina, Saskatchewan, Canada S4S 5W6.

The GenBank/EMBL/DDBJ accession numbers for the 16S rRNA gene sequences of strains $H^{\top}$ and S-308-81 are AY293856 and AY398688, respectively. were determined by using the hydroxyapatite method, at an optimal reassociation temperature of $55^{\circ} \mathrm{C}$. The DNADNA relatedness (relative binding ratio) was $81 \%$ and the percentage divergence in related DNA sequences was $0 \cdot 2 \%$ (Table 1 ). These two strains meet the criteria for the molecular definition of a species (Brenner et al., 1999). DNA-DNA relatedness studies (Table 1) have shown Leptospira parva strain $\mathrm{H}^{\mathrm{T}}$ to be distinct from strains of other Leptospira species and from Leptonema illini (Brenner et al., 1999).

A proposal was made at the ICSB Subcommittee on the Taxonomy of Leptospira (TSC) meeting in 1990 to transfer Leptospira parva from the genus Leptospira to a newly created genus, 'Turneria', as 'Turneria parva' (Marshall, 1992). This proposal was agreed to at the TSC meeting, but apparently was not prepared for publication, so the name currently has no standing in nomenclature. The nomenclature of this species has become a source of confusion, with some authors referring incorrectly to Leptospira parva as Leptospira parva incertae sedis (Hookey, 1993) and others using the genus name 'Turneria', which has no standing in nomenclature. Moreover, the genus name 'Turneria' is illegitimate because it is the name of genera of both plants (Dicotyledones: Turneraceae) and animals (Formicidae, Hymenoptera and Sauropterygia, Reptilia).

In order to clarify this situation, we propose the transfer of Leptospira parva to the genus Turneriella as Turneriella parva gen. nov., comb. nov., with strain $\mathrm{H}^{\mathrm{T}}$ as the type strain (Hovind-Hougen et al., 1981). We believe that this fulfils the original intention of the proposal minuted from the 1990 TSC meeting (Marshall, 1992). The description of T. parva is given below, and the description of the family Leptospiraceae Hovind-Hougen 1979 is emended, to take into account the proposed changes. 


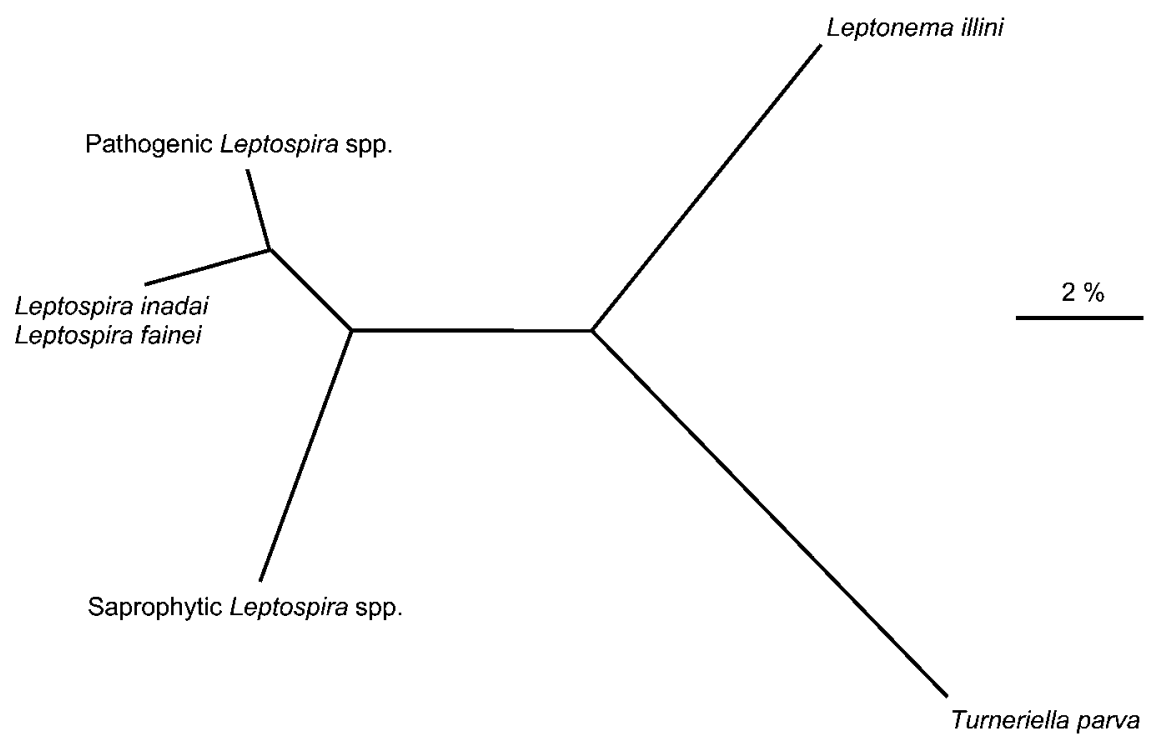

Fig. 1. Phylogenetic relationships between the genera of the family Leptospiraceae. The unrooted tree was obtained by neighbour-joining 16S rRNA gene sequences representing the leptospiral clades, Leptonema illini and T. parva. The 16S rRNA genes of strains of known species were resequenced to near full-length and high redundancy before further analysis. Neighbour-joining was implemented on CLUSTAL_X-aligned sequences, with branch placement analysed by bootstrapping 1000 times for confidence resulting in all branch values of 1000 (not shown). The tree was drawn using TreeExplorer. Bar, 29 nucleotide substitutions per 1454 aligned base pairs. GenBank/EMBL/DDBJ accession numbers are as follows. Pathogenic Leptospira spp.: Leptospira borgpetersenii serovar Ballum strain Mus 127, AY631884. Intermediate Leptospira spp.: Leptospira inadai serovar Lyme ${ }^{\top}$, AY631896; Leptospira fainei serovar Hurstbridge strain BUT $6^{\top}$, AY631885. Saprophytic Leptospira species: Leptospira biflexa serovar Patoc strain Patoc I ${ }^{\top}$, AY631876. Leptonema illini serovar Illini strain $3055^{\top}$, AY714984. T. parva strain $\mathrm{H}^{\top}$, AY293856.

Table 1. DNA-DNA relatedness between $T$. parva $\mathrm{H}^{\top}$ and reference strains of Leptospira species and Leptonema illini

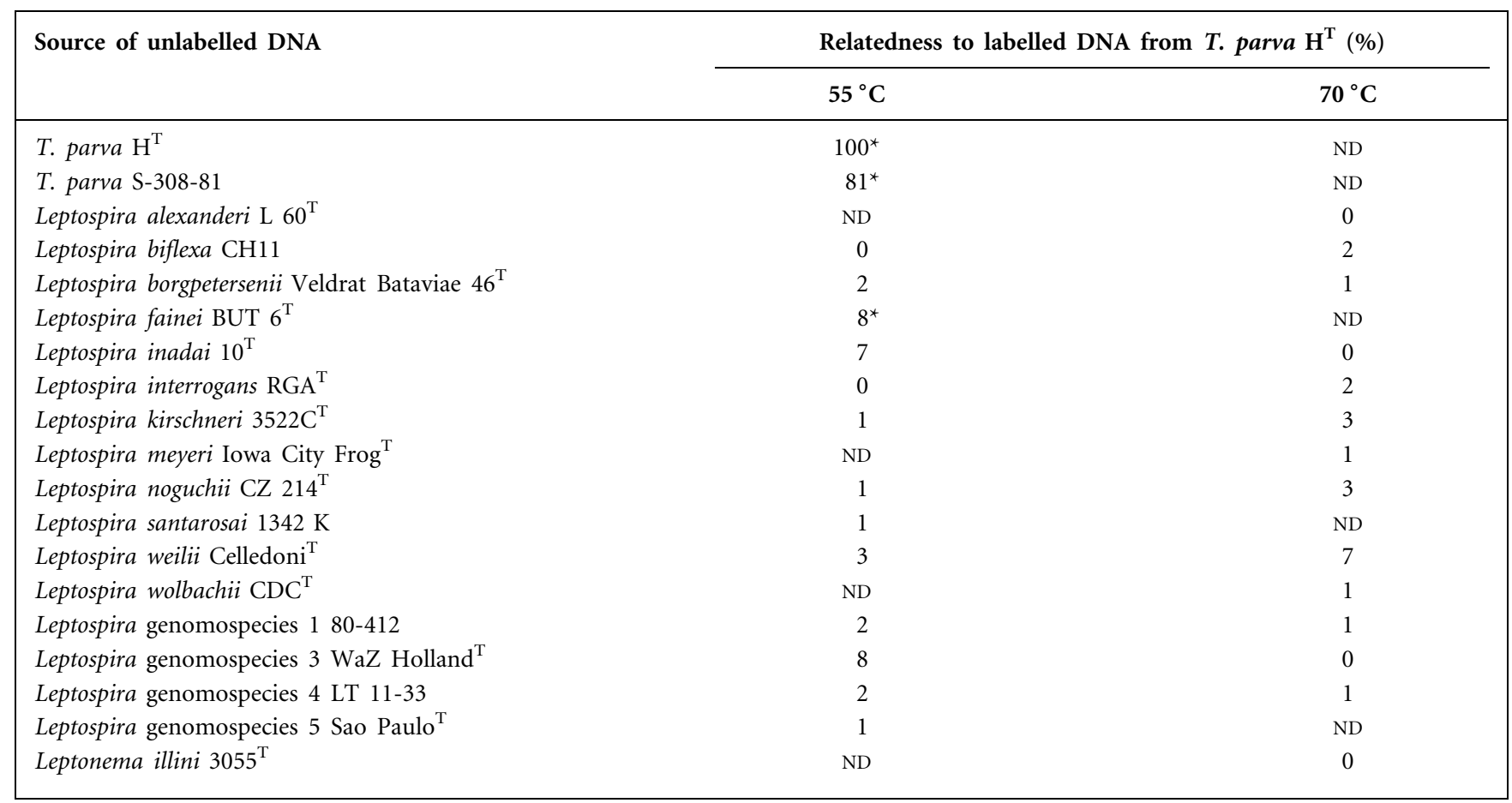

ND, Not done.

${ }^{*}$ Data from this study. All other data from Brenner et al. (1999). 


\section{Emended description of Leptospiraceae Hovind-Hougen 1979}

Comprises three genera, Leptospira, Leptonema and Turneriella, defined by differences in $\mathrm{G}+\mathrm{C}$ content, DNA-DNA relatedness and 16S rRNA gene sequences. The G $+\mathrm{C}$ contents of the genera Leptospira, Leptonema and Turneriella are 33-43, 54 and $48 \mathrm{~mol} \%$, respectively (Yasuda et al., 1987). Other characteristics are as described previously (Hovind-Hougen, 1979; Johnson \& Faine, 1984). The type genus is Leptospira Noguchi 1917.

\section{Description of Turneriella gen. nov.}

Turneriella (Tur'ne.ri.el.la. N.L. fem. n. Turneriella to honour Leslie Turner, an English medical microbiologist who made definitive contributions to the knowledge of leptospirosis).

Cells are Gram-negative, flexible and helical, measuring $0 \cdot 3 \times 3 \cdot 5-7 \cdot 5 \mu \mathrm{m}$; wavelength is $0 \cdot 3-0.5 \mu \mathrm{m}$ (HovindHougen et al., 1981). Motile by means of two axial filaments. Obligately aerobic. Oxidase-positive. The type species is Turneriella parva (Hovind-Hougen et al. 1982) Levett et al. 2005.

\section{Description of Turneriella parva comb. nov.}

Turneriella parva (par'va. L. fem. adj. parva small).

Basonym: Leptospira parva Hovind-Hougen et al. 1982.

Exhibits the following characteristics in addition to those given in the genus description. DNA $\mathrm{G}+\mathrm{C}$ content is $48 \mathrm{~mol} \%$ (Yasuda et al., 1987). Growth is inhibited by $200 \mu \mathrm{g} 8$-azaguanine $\mathrm{ml}^{-1}$ and $10 \mu \mathrm{g}$ 2,6-diamonopurine $\mathrm{ml}^{-1}$. Produces lipase. Grows at 13,30 and $37^{\circ} \mathrm{C}$ after prolonged incubation. Strains have been isolated from contaminated culture medium, from tap water and from the uterus of a sow. Not pathogenic for hamsters. The type strain is $\mathrm{H}^{\mathrm{T}}\left(=\right.$ NCTC $11395^{\mathrm{T}}=$ ATCC BAA- $\left.1111^{\mathrm{T}}\right)$.

\section{Acknowledgements}

We thank Professor Dr Hans Trüper for his kind advice regarding the etymology of the genus name.

\section{References}

Brenner, D. J., McWhorter, A. C., Knutson, J. K. \& Steigerwalt, A. G. (1982). Escherichia vulneris: a new species of Enterobacteriaceae associated with human wounds. J Clin Microbiol 15, 1133-1140.

Brenner, D. J., Kaufmann, A. F., Sulzer, K. R., Steigerwalt, A. G., Rogers, F. C. \& Weyant, R. S. (1999). Further determination of DNA relatedness between serogroups and serovars in the family Leptospiraceae with a proposal for Leptospira alexanderi sp. nov. and four new Leptospira genomospecies. Int J Syst Bacteriol 49, 839-858.

Hookey, J. V. (1993). Characterization of Leptospiraceae by $16 \mathrm{~S}$ DNA restriction length polymorphisms. J Gen Microbiol 139, 1681-1689.

Hookey, J. V., Bryden, J. \& Gatehouse, L. (1993). The use of $16 \mathrm{~S}$ rDNA sequence analysis to investigate the phylogeny of Leptospiraceae and related spirochaetes. J Gen Microbiol 139, 2585-2590.

Hovind-Hougen, K. (1979). Leptospiraceae, a new family to include Leptospira Noguchi 1917 and Leptonema gen. nov. Int J Syst Bacteriol 29, 245-251.

Hovind-Hougen, K., Ellis, W. A. \& Birch-Andersen, A. (1981). Leptospira parva sp. nov.: some morphological and biological characters. Zentralbl Bakteriol Mikrobiol Hyg A 250, 343-354.

Johnson, R. C. \& Faine, S. (1984). Genus I. Leptospira Noguchi 1917, 755. AL In Bergey's Manual of Systematic Bacteriology, vol. 1, pp. 62-67. Edited by N. R. Krieg \& J. G. Holt. Baltimore: Williams \& Wilkins.

Marshall, R. (1992). International Committee on Systematic Bacteriology Subcommittee on the Taxonomy of Leptospira. Minutes of the meetings, 13 and 15 September 1990, Osaka, Japan. Int J Syst Bacteriol 42, 330-334.

Perolat, P., Chappel, R. J., Adler, B., Baranton, G., Bulach, D. M., Billinghurst, M. L., Letocart, M., Merien, F. \& Serrano, M. S. (1998). Leptospira fainei sp. nov., isolated from pigs in Australia. Int J Syst Bacteriol 48, 851-858.

Ramadass, P., Jarvis, B. D. W., Corner, R. J., Penny, D. \& Marshall, R. B. (1992). Genetic characterization of pathogenic Leptospira species by DNA hybridization. Int J Syst Bacteriol 42, 215-219.

Yasuda, P. H., Steigerwalt, A. G., Sulzer, K. R., Kaufmann, A. F., Rogers, F. \& Brenner, D. J. (1987). Deoxyribonucleic acid relatedness between serogroups and serovars in the family Leptospiraceae with proposals for seven new Leptospira species. Int J Syst Bacteriol 37, 407-415. 